The bridge was severely tested by Gen. Hutchinson, the Government Inspector of Railways, in February of this year. Five locomotive engines of 72 tons weight each were placed on the large spans and run over them at considerable speed. This weight of 360 tons for each of the $245^{\prime}$ spans will never be reached in the working of the railway, 162 tons being the greatest load resulting on each span from the heaviest goods train. Under the test load the deflection of any of the spans did not exceed the calculated limit, and the lateral movement during the passage of trains was but trifling.

On June I the bridge was opened for ordinary traffic, and it is now daily crossed by numerous and heavy trains. For the North British Railway Company and the travelling public its completion is of very great importance. But the work must have a still greater importance in the eyes of engineers and those interested in the practical application of scientific principles, as many new methods to overcome formidable difficulties were successfully carried out, some of which might with advantage be used in similar structures.

A. GROTHE

\section{THE NORWEGIAN NORTH ATLANTIC EXPEDITION}

THE expedition left Bergen on June I5, and proceeded without interruption to the Westfjord, in Nordland, where we had our first station. A temperature-series was here taken with Negretti and Zambra's new deep-sea thermometer, which showed $10^{\circ} 7 \mathrm{C}$. on the surface, a minimum of $4^{\circ} 4$ in a depth of 40 fathoms, and $6^{\circ} .5$ at the bottom in 340 fathoms. The Vöringen stopped some hours at Tromsö to take on board a pilot, and proceeded to the Altenfjord, where we found $7^{\circ} \cdot 3$ at the surface, a minimum of $2^{\circ} 7$ in a depth of 100 fathoms, and $3^{\circ} 9$ in 220 fathoms at bottom. From Alten we went to Hammerfest, where we stayed two days. Our next stations were in the Porsangexfjord and in the Tanafjord. On all these stations we dredged and trawled with good success. On June 26 we were lying at Wardö, where Capt. Wille made magnetical observations of force and inclination. The declination was determined the day before off the coast by going round with the ship, and taking bearings of the sun on different courses. On June 27 we put to sea on an eastward course. The barometer was falling rapidly, and at midnight the wind and sea got so heavy, that the ship was put with the stem against the wind, and we were lying almost still. This situation lasted till the next night, when we again proceeded on our course, but very slowly, the ship pitching heavily, and the wind being constantly ahead. In this manner we found $0^{\circ} \mathrm{C}$. at the sea bottom, in about $71^{\circ} 30^{\prime} \mathrm{N}$. and $36^{\circ} 30^{\prime} \mathrm{E}$. from Green wich. We then sailed northwards and westwards, and passed the said bottom temperature several times, so that I am now able to give its situation pretty accurately in the chart. The northern part of this zero line forms a bay east of Bear (Cherry) Island, where the warmer water reaches a higher latitude, and runs close to the east side of that island, where we for the first time observed the polar ice. The temperature-series showed the accuracy of Weyprecht's observations, that the colder Polar water edges itself along the bottom from the east and north, and the warm Atlantic water runs out in a similar edge in the contrary direction towards Novaya Zemlya and Franz-Joseph Land. On July 4 we were at Bear Island, on the south-east side. We were happy to find the sky almost perfectly clear, a ratber rare occurrence on this island. The ship was anchored outside the open coast, and we went on shore at the mouth of a little river, in the vicinity of which there stands a hut, which has been the abode of wintering parties. Here we deposited the mail which we brought for the Dutch polar exnedition in the Wilhem Barentz schooner. The place was marked with a flag, and the letters, \&c., dug down, inclosed in an outer wooden and an inner sheet-iron soldered box. I took a tour upon the nearest hills, collected some rock specimens, and measured the altitude of the highest peak on Bear Island, Mount Misery. The calculation gave me a height of 1,787 English feet, a result which I regard as very accurate. After dinner we weighed and proceeded to the south-west; crossed, the following day, the zero line of bottom temperature on the bank between Bear Island and Norway, sounded in 1,024 fathoms on July 6 in lat. $73^{\circ} 6^{\prime} \mathrm{N}$, , long. $11^{\circ} 56^{\prime}$ E.; we went then east-south-eastwards, crosșed again the zero temperature line, and shaped our course for Hammerfest, where we arrived on the 8th. The ship is now cleaned; we take in coal, and expect to be ready to sail on a westward cruise in three days. Our first cruise has yielded thirty-eight soundings, seventeen temperature series, ten dredgings, and seven trawlings, all successful, New species of animals have been found by our zoologists. Negretti and Zambra's newest reversible deep-sea thermometer has done us great service; the instrument has, almost without exception, worked very well. I have constantly compared its readings from the bottom with the reading of the Casella, Bucbanan's improved form, and found a very close agreement. As I supposed, the wooden box which carries the thermometer gets watersoaked after a few experiments in a few hundred fathoms, so that it no longer floats, but this is no drawback, as the lead rushes down so fast that the thermometer always keeps its upright situation till it reaches the bottom, and it never requires more than three minutes for a perfect accommodiation to $O^{\prime} I$ of a degree. I therefore regard this instrument as a very important improvement, and feel much obliged to the inventors and makers.

Hammerfest, July ro

H. MOHN

\section{THE TASTMETER}

TR. EDISON has applied the principle of his carbon telephone to a new instrument which is said to be a measurer of infinitesimal pressure. The principle is the variation of the electric resistance of a carbon button due to variation of pressure, and the instrument is said to be an extremely delicate thermoscope. We have not yet, however, received any authentic account of its performance or of its accuracy, but its ingenuity certainly deserves a description, for which we are indebted to the Scientific Anterican.

It is the outcome of Mr. Edison's carbon telephone. Having experimented with diaphragms of various thicknesses, he ascertained that the best results were secured by using the thicker diaphragms. At this stage, however, he experienced a new difficulty. So sensitive was the carbon button to changes of condition, that the expansion of the rubber telephone handle rendered the instrument inarticulate, and finally inoperative. Iron bandles were substituted with a similar result, but with the additional feature of musical and creaky tones distinctly audible in the receiving instrument. These sounds Mr. Edison attributed to the movement of the molecules of iron among themselves during expansion. He calls them "molecular music." To avoid these disturbances in the telephone, the handle was dispensed with; but it had done a great service in revealing the extreme sensitiveness of the carbon button, and this discovery opened the way for the invention of the new and wonderful instrument.

The micro-tasimeter is represented in perspective in Figs. I and 2, in section in Fig. 3, and the plan upon which it is arranged in the electric circuit is shown in Fig. 4.

The instrument consists essentially of a rigid iron frame for holding the carbon button, which is placed between 